\title{
Research on Cultivation Mechanism of Key vocational Ability Under General Education \\ Tingting $\mathrm{Ou}$ \\ Guangzhou Kangda Vocational Technical College, Guangzhou, 511363, China
}

\begin{abstract}
The vocational technical school is the cradle that cultivates high-skilled talents. The higher vocational students do not only accept higher education, but also accept vocational education. The talents cultivation mode of vocational technical school determines the comprehensive quality of high-skilled talents and plays a critical role in China's economic development. In the past dozens of years, the talents cultivation mode of higher vocational school is continuously improved with the requirements of the society on the high-skilled talents, which is conducive to the cultivation of high-level technicians in a certain sense. However, to make China's economic construction reach the world leading level, the society has higher and higher requirements on the high-skilled talents and the vocational technical school is urgently required to change the talents cultivation method. Therefore, the talents cultivation mode is studied deeply according to the educational features of higher vocational school and high requirements of the society on qualified high-skilled talents.
\end{abstract}

Key words: Higher vocational education; talents cultivation mode; general education; high-skilled talents

In the modern society, the high-skilled talents are valued in all walks of life and the general education becomes the primary talents cultivation mode in China's higher vocational school. China's higher vocational school has such a common phenomenon: the school only pays attention to the professional skills and employment training, regardless of the cultivation of students' humanistic feelings, social skills and other comprehensive quality. This situation is conducive to students' all-around development and imposes serious influences on their interpersonal skills and social 
adaptability. The general education can change this bad situation and is highly valued by China's government and educational circles.

\section{Problems in China's talents cultivation mode}

\section{Higher vocational education mode hinders the improvement of vocational skills}

At present, China's higher vocational education mode is old, so it is required to combine the cultivation of vocational technical ability with the general education to change the limitation of vocational education of ordinary technical secondary school, technical school, higher vocational school and other schools in the past so as to make it keep up with the social development and meet the scientific and technological development needs in the future, thus promoting the development of China's socialist modernization construction at maximum.

China's higher vocational education is not mature and still has three problems. First, the number of high-level and high-quality professional teacher and scientific research tutor cannot meet the teaching and scientific research needs. The professional teacher and scientific research personnel of higher vocation school are the key to ensure the close relationship between vocational technical ability and general education and can improve the teaching level and educational quality of vocational technical school. However, China’s higher vocational school lacks of high-quality professional teacher and versed scientific research personnel and the in-service teacher and scientific research personnel at school fail to accept professional training of vocational education theory. It is found after survey that the vocational technical school's current minimum standard for the recruitment of professional teachers is the teachers with master degree and rich professional knowledge, but such teachers fail to conduct many researches on the higher vocational education and don't know the rules and attentions of higher vocational teaching, so they cannot really integrate into the teaching of higher vocational education. Second, there is no insufficient time to ensure the cultivation of the vocational ability of students at school. The students' vocational ability is not only embodied in the ability, but also embodied in the richness of knowledge. To make students have solid professional knowledge and high 
vocational quality as well as excellent professional skills, the sufficient education time is the key to promote their all-around development. Next, China's higher vocational education level cannot keep up with the scientific and technological development in the future society. According to the current scientific and technological development speed, the future society will have higher requirements on the scientists and technicians, so we are required to change the current higher vocational education mode and improve the higher vocational education level to lay a solid theoretical and practical foundation for the better higher vocational education in the future and accompany the scientific and technological development in the future.

\section{Higher vocational education pays less attention to the general education and}

\section{fails to deeply realize the cultivation of vocational ability}

The higher vocational school is the cradle that cultivates high-skilled talents and the higher vocational education plays a critical role in the vocational education. The higher vocational education does not only require students to master the all-around professional knowledge, but also require them to have strong professional skills to improve their comprehensive ability. Adhering to the purpose of cultivating talents and promoting students' all-around development, the talents cultivation of higher vocational school pays attention to cultivate students' humanistic feelings, social adaptability, sustainable development and other abilities and promote the harmonious development of their body and mind. The higher vocational school should correct students' educational thought, pay attention to cultivate students' all-around knowledge and various abilities and make the general education run through the teaching of higher vocational education to make students predict China's social economic development direction, deeply experience the change rule of vocational education in the future and requirements of vocational education in the future on the vocational ability of scientists and technicians, and have a comprehensive understanding of the future vocational features and the close relationship between knowledge and ability cultivation, and to combine the cultivation of vocational technical ability and general education and make them develop longitudinally. This is of important significance in comprehensively improving the comprehensive ability of 
higher vocational students.

However, China pays more attention to the position requirements of current occupation and then cultivates students' actual operability by setting the specific course teaching and classroom content, regardless of students' systematic education, so students cannot have all-around development. In this case, students cultivated can meet the contemporary single social needs. With the social development and rapid economic development, the talents needs of the society are more and more comprehensive and the occupation must change. The students fail to really master the knowledge and skills that must be mastered, students' all-around cultivation and development are just an empty talk and the cultivation of students' humanistic quality is hard to really implement. For example, the school has no clear positioning and direction in students' cultivation and major setting and only pays attention to the present, without any development thinking, so the talents cultivated are hard to have a long-term development. The course arrangement of school just stays on the complete significance of discipline and students are not cultivated according to the real needs of major. In class, the teacher's explanation is self-centered and the teacher lacks of basic communication with students and fails to pay attention to students' independent thinking and problem-solving ability, which seriously hinder the exercise and cultivation of students' actual operability. Therefore, the "vocational" cultivation is hard to implement.

\section{Suggestions and countermeasures for the cultivation of vocational ability of higher vocational students}

\section{Make students' comprehensive quality have all-around development}

The comprehensive quality education of higher vocational schools is mainly at the humanistic knowledge level, regardless of the contemporary actual social factors, natural environment and natural society. Therefore, the educational strength in science and technology, political theory and social ideology. The courses of National Kaohsiung University of Applied Sciences include humanistic education and artistic culture, establishment of group of natural science and technology, management mode of social ideology, enlightenment of historical events on thinking, formulation of law 
and ethical relationship and other modules. The Chinese University of Hong Kong sets four modules in general education, including cultural inheritance, relationship between natural environment and science and technology, social ideology and humanistic relation as well as relationship between individual values and humanity. The higher vocational education can meet the social and human development needs for a long time in the future only by effectively integrating the general education and professional vocational education. The school should positively carry out various activities to make students have all-around development to meet the social needs at present and for a long time in the future.

The higher vocational school can realize the effective integration of the above process by cultivating students' professional vocational skills and improving their comprehensive quality. As the specific form and effective carrier of general education, the cultivation of comprehensive ability is important. From the vocational perspective, the comprehensive quality is the comprehensive education based on the current society and labor's adaptability, in which the students' basic operability is taken as the cultivation object and the personal basic quality is valued. However, the general education, which is put forward from the perspective of human's long-term sustainable development, is an ability education model to cultivate students' creative awareness, social responsibility and personal all-around development to make them develop a good habit of life-long learning. The combination of the two education modes is of positive significance in promoting students' all-around development and lays a solid foundation for the late development of students.

\section{Increase the investment in teaching team}

The vocational education and general education can be effectively combined and more useful talents can be cultivated only when there are sufficient training devices and high-quality and high-level teaching team. Therefore, the higher vocational schools should increase the relevant training device and conduct necessary training of relevant teachers to improve the teachers' personal comprehensive quality and ability. However, many higher education institutions have the capital shortage problem. To solve this problem, the institutions should do the following: first, based on the current 
social needs and national research project, apply to the national and local governmental departments for the relevant research fund to solve the current social needs. Then, grasp the opportunity of national educational project to strive for national supports and relevant fund. Finally, strengthen the contact with all sectors of the society, positively give play to the technical and theoretical advantages to provide necessary assistance to the society to get social support and capital investment. The teacher should have regular training to meet the current social needs.

To meet the above requirements, the higher education institutions should do the following: first, develop proper cultivation plan and specific implementation steps, do the regular training well, use proper methods to make the teacher know the latest social information timely so as to make adjustment to meet the current social needs and reform the teaching mode. Second, choose proper and potential teachers to conduct learning and survey in the relevant enterprise to make them better master the enterprise's production mode and specific process, strengthen the teachers' actual operability, enhance students' understanding of knowledge and make the teaching more efficient. Enhance the communication and cooperation between the teacher and students to effectively improve students' learning ability and efficiency.

\section{Implement general education in China}

At present, the higher vocational education pays more attention to the cultivation of relevant professional positions, regardless of the cultivation of students' comprehensive ability as well as education of humanistic quality and cultivation of perfect personality. Therefore, it is urgent for the higher education institutions to conduct general education. However, the higher education institutions are different greatly in schooling length and course arrangement, in which the schooling length of some institutions is short, so the task of relevant skill training is heavy, and students' basic quality and learning level are also different greatly. The higher vocational school cannot completely copy the education mode of ordinary university in students' vocational education and should set more course with wide knowledge span and knowledge depth, increase the relevant class hour, conduct more humanistic education and make extracurricular learning become an important way of enriching students' 
knowledge and improving their self-cultivation. In addition, it is required to form a strong learning atmosphere on the campus, highlight the practical operability, make the basic principles of conducting oneself run through the specific actual operation and improve students' vocational skills. We can make the specific educational concept run through students' daily life and learning, be clear about the student cultivation goal, reform the classroom content, put more energy into the teaching method, cultural life on campus and actual operation so as to strengthen students' humanistic quality and improve their professional skills.

\section{Conclusion}

As a part of national education, the higher vocational education bears the important responsibility of cultivating qualified high-level technical talents for the state. However, China's higher vocational education is in the initial stage, the theory and relevant device of higher education are not perfect and cannot meet the current social needs well, and the higher technical education level cannot meet the social needs at present and for a long time in the future and provide powerful assistance in the construction of socialist modernization. Therefore, on the promise of not violating the things development rule, we should refer to our current situation, make a bold attempt to establish a system that is more suitable for our higher vocational education and summarize the proper higher vocational education theory to push our higher vocational education to a new level.

\section{References:}

[1] Li Manli, Lin Xiaoying. General Education Practice in Post-Industrial Age-Taking Peking University and Chinese University of Hong Kong as Examples[M]. Beijing: Nationalities Publishing House, 2003.

[2] Purpose of Vocational Education is To Make Students Have Full Employment--News From 2007 International Vocational Education Development Forum[J]. Chinese Vocational and Technical Education, 2007,(30).

[3] Liu Chujia. Practice of General Education of Higher Vocational Technical Schools in Taiwan and Its Enlightenment[J]. Education and Vocation, 2007,(12). 
[4] Jiang Dayuan. Research on Mainstream Teaching Thought of Contemporary

German Vocational Education--Theory, Practice and Innovation[M]. Beijing: Tsinghua University Press, 2007.

[5] Wu Lingke. On Elements of Cultivating Vocational Key Ability of Higher Vocational Students_— Taking Wuxi Higher Vocational School of Tourism \& Commerce as an Example[J]. Journal of Wuxi Higher Vocational School of Tourism \& Commerce, 2008(06) .

[6] Li Chanhui, Liu Yanshu. Introducing Indian Education System and Enhanci ng Students' Vocational Key Ability[J]. Journal of Hunan Mass Media Vocation al Technical College, 2009(03) 